\title{
破壊力学手法によるひび割れ分散を考慮した繊維補強軽量コンクリートパネル の曲げ破壊解析

\author{
FRACTURE MECHANICS BASED BENDING FAILURE ANALYSIS \\ FOR FIBER REINFORCED LIGHT-WEIGHT CONCRETE PANEL \\ CONSIDERING CRACK DISPERSION EFFECT
}

\author{
橘高義 典*，高 橋 仁 智** \\ Yoshinori KITSUTAKA and Yoshinori TAKAHASHI
}

\begin{abstract}
In this study, the fracture process of strain softening and hardening material which has the crack dispersion and localization characteristics was studied. Numerical analysis method to calculate the load displacement relationship of the member which has multiple cracking subjected to the bending was proposed based on the fracture mechanics consideration. Bending tests of the fiber reinforced light-weight concrete panel were performed. Influences of the fiber content and the air content on the mechanical properties and on the crack dispersing effect were cleared. Especially, the fiber reinforced light-weight concrete containing air showed high crack dispersion under the bending condition. Tension softening diagram of fiber reinforced light-weight concrete which can be used as a constitutive law for the numerical analysis were evaluated by the data of a load - crack mouth opening displacement (CMOD) relationships obtained by the wedge splitting test. The analysis results of the bending tests agreed well with the test results.
\end{abstract}

\section{Keywords : fiber reinforced light-weight concrete, multiple cracking, strain hardening, fracture mechanics,} tension softening diagram, localization

織維補強軽量コンクリート, 複数ひび割れ，ひずみ硬化，破壊力学，引張軟化曲線，局所化

\section{1. はじめに}

近年, コンクリート材料の高性能化に関する研究が多くなされて いるが，特に綫維補強によるコンクリートの高勒性化は，破壊進展 時のエネルギー吸収を増大させるため,コンクリート部材の安全性 能・耐久性能向上等の観点から重要な研究課題である。䄉維補強コ ンクリートの破壊進展の特徵として, ひび割れ発生後も織維のブリ ッジング作用により引張応力が伝達され, 従来のコンクリートの脆 性的な破壊に比べて, より延性的な破壊となることが挙げられる。 さらに紻維条件あるいはマトリックス条件によっては, ひび割れ発 生後も伝達応力が上昇する，いわゆるひずみ硬化(strain hardening) を示すものもある。部材の破壊過程で部分的に硬化が生じると, 他 の部分に新たなひび割れが発生し破壊部分が分散する。そのことで 破壊時のエネルギー吸収能が増大するとともに, ひび割れの局所化 による脆性的な破壊を低減でき，理想的な破壊形熊となる。

このような織維補強材料の引張破壊時の挙動は, 引張軟化特性と して実験的及び解析的に評価することが可能であり ${ }^{11,2)}$, 多くの織 維補強コンクリートについてその特性が明らかにされている ${ }^{3) .4\rangle}$ 。 また, 織維補強材料の応力伝達機構に関する基礎的研究も報告され
ている(5),6)。しかしながらそれらは破壊部分を一部に限定した要素 レベルでの評価であり，実際の部材の破壊に見られるようなひび割 れの分散をモテル化した研究は数少ない。特に部材の荷重変形関係 の数值解析を行うためは, 破壊部分の分散・局所過程のモデル化が 重要となる。

一方でこのような紻維補強コンクリートの適用例として，建築用 2 次部材, カーテンウォール, パネル材料等が挙げられるが, これ らは軽量化が望ましく，筆者らは前報”において紻維補強軽量コン クリートのマトリックスを高強度とすることで, 軽量化を図りなが ら十分な強度が得られ, かつ勒性能が優れるコンクリート材料が得 られることを実験的に示した。これら材料のパネル部材への適用性 を検討するためには，曲げ荷重時の破壊特性およびひび割れ分散性 能を把握することが重要と考えられる。

本報では，軟化及び硬化現象を生じる複合材料の破壊について考 察し，破壊の分散及び局所化の簡便なモテルを示すとともに，パネ ル材レベルでの荷重変形関係の解析方法を提案する。さらに瀻維補 強された軽量コンクリートパネルの曲け破壊性状を把握するととも に, 荷重変形関係について提案した解析方法の妥当性を検討する。

\footnotetext{
* 東京都立大学大学院工学研究科建築学専攻 助教授. 工博 Assoc. Prof., Dept. of Architecture and Building Science, Graduate School of Eng., 


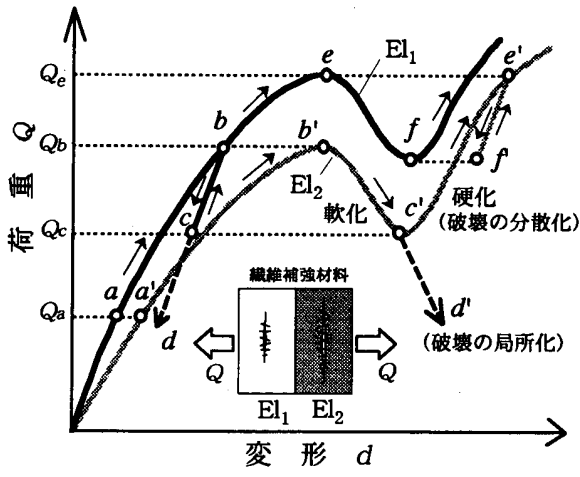

図一 1 引張軟化及び硬化を生じる要素相互 の荷重変形関係

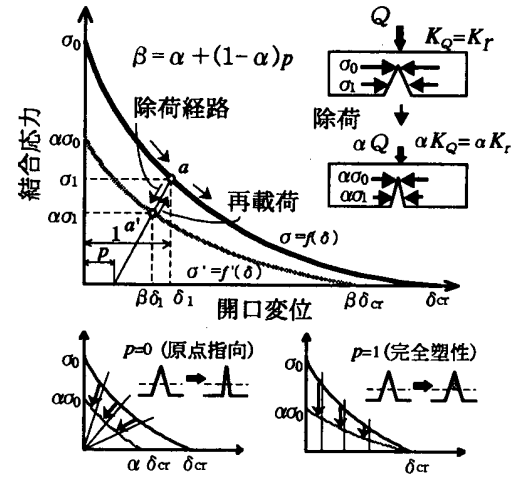

図一2 引張軟化曲線での除荷・再載荷 モデル

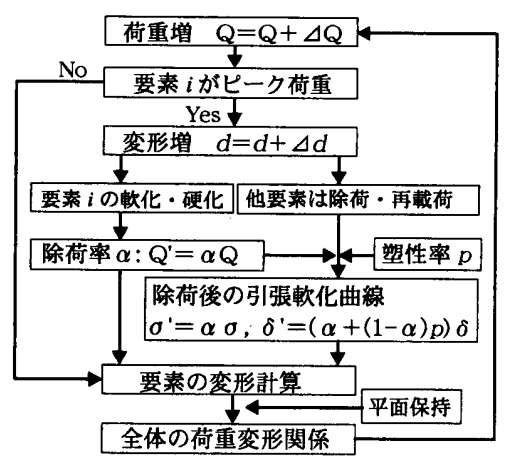

図一3 除荷・再載荷を考虑した荷重変 位解析フロー

\section{2. 解析方法}

2.1 破壊の分散及び局所化のモデル及び解析方法

図一 1 は, 同一材料であるが初期欠陥の大きさに差があり荷重変 形関係が異なる, 引張軟化・硬化を示す非線形要素 $\mathrm{El}_{1}, \mathrm{El}_{2}$ (織維補 強材料等)が直列している場合での破壊進展過程を模式化したもの である。まず, 荷重の増加に伴い各要素には徐々にひび割れが生じ るが $\left(a, a^{\prime}\right)$, 初期欠陥の大きな $\mathrm{El}_{2}$ のひび割れ進展が先行し, ピーク 荷重 $\left(Q_{b}\right)$ を過ぎると, $\mathrm{El}_{2}$ は徐々に軟化し要素間の伝達力が低下して 行く $\left(Q_{b} \rightarrow Q_{c}\right)$ 。その結果, $E l_{1}$ は除荷経路をたどる $(b \rightarrow c)$ 。この場合 残留変形があるため完全にaには戻らない。その後 $\mathrm{E}_{2}$ がさらに軟化 を䌇けると $\mathrm{El}_{2}$ に破壊が局所化しその部分の破壊が大きく進み $\left(d^{\prime}\right)$, 逆にEl,のひび割れは閉口に向かう $(d)$ 。コンクリート等の通常の軟 化材料はこのような破壊の局所化現象を示し破断に至る。ところが $c^{\prime}$ の点から $\mathrm{El}_{2}$ が硬化現象を示すと $\left(c^{\prime} \rightarrow e^{\prime}\right), \mathrm{El}_{1}$ は再載荷状態となり $(c$ $\rightarrow b)$, さらに, 荷重が $Q_{b}$ を過ぎるとEl $l_{1}$ の破壊が再度進行しはじめ $(b \rightarrow e)$ 破壊部の再分散化が起こる。さらに荷重が增加しEl $1_{1}$ がピーク 荷重 $\left(Q_{e}\right)$ を超えると, 今度はEl どる $\left(e^{\prime} \rightarrow f^{\prime}\right)$ 。このような複雑な経路をたどりながら，各要素の破 壊が連䌇的に進行し，大きなエネルギー吸収を生じる。

また, 図一 1 の $b \rightarrow c に$ 示される除荷過程での引張軟化曲線の変化 (除荷時の見かけの開口変位一結合応力関係)は図-2のように考え ることができる。まず荷重がQ $Q_{b} \rightarrow Q_{c} に$ 低下した場合，ひび割れは先 端部から一定の割合で閉口するとみなすと, 結合応力 $\sigma$ は除荷率 $\alpha$ $=Q_{c} / Q_{b}$ だけ一様に線形に低下し $\sigma^{\prime}$ となる(式(1))。開口変位 $\delta$ は， $a$ に塑性率 $p$ を考慮し式(2)で表せる。塑性率 $p$ は除荷によりひび割 れが閉口する程度を表し，原点指向の場合は $p=0$, 除荷後も開口変 位が変化しない完全塑性の場合は $p=1$ となる。再載荷では除荷経路 を戻り除荷開始点からは本来の引張軟化曲線に従う(図 -2 参照)。

$$
\sigma^{\prime}=\alpha \sigma ; \delta^{\prime}=(\alpha+(1-\alpha) p) \delta
$$

式(1), (2)に従って除荷後の開口変位の分布が求められ要素の変 形が計算できる。各要素間の応力伝達に平面保持を仮定し, 各要素 の変形を計算し全てを重ね合わせることで部材全体の荷重一変形関 係が求められる。以上の解析フローを図ー 3 に示した。

\section{2 純曲げ破壊解析}

ここでは，純曲げを受ける部材の解析法を検討する。まず 1 要素 の破壊進展を結合力モデルで表す(図ー4)。仮想ひびわれ先端での

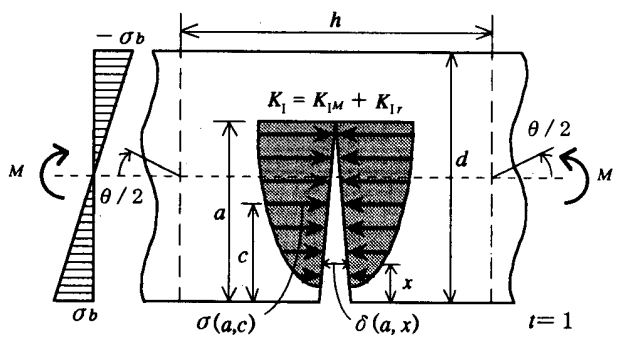

図-4 曲げ要素のモードI 変形破壊での結合力モデル

応力拡大係数の釣合, ならびに応力桩大係数から算出される各節点 の開口変位の適合より下式が得られる。

$K_{\mathrm{I} M}(a)+K_{\mathrm{Ir}}(a)=0$

$\delta(a, x)=\delta_{M}(a, x)+\delta_{r}(a, x)$

ここに， $K_{\mathrm{m}}(a), K_{\mathrm{Ir}}(a)$ : それぞれ，ひびわれ長さ $a$ の時のモーメ ント $M$, 結合応力による応力拡大係数(モード I), $\delta(a, x): x$ での 開口変位, $\delta_{M}(a, x), \delta_{r}(a, x):$ それぞれ $x$ でのモ一メント, 結合応力に よる開口変位である。応力拡大係数は, モーメントMによる場合は 式(5), 結合応力のによる場合は式(6)で表せる ${ }^{8)} 。 F, G は$ 形状関数で ある (Appendix I 参照)。各記号は図ー4を参照されたい。

$$
\begin{aligned}
& K_{\mathrm{I} M(a)}=6 M / d^{2} \sqrt{\pi a} \cdot F(a, d)=M \cdot k_{M^{\prime}}(a) \\
& K_{\mathrm{I}_{r}}(a)=\int_{0}^{a} \frac{2 \sigma(a, c)}{\sqrt{\pi a}} \cdot G(a, c, d) d c=\int_{0}^{a} \sigma(a, c) \cdot k_{r}(a, c) d c
\end{aligned}
$$

任意部の変位は, Castiglianoの定理により, 応力拡大係数の積 分式次式で表せる8。

$$
d y=d_{0}+\int_{x}^{a} \frac{2 \cdot K_{(z)}}{E}\left[\frac{\partial K_{f}(z)}{\partial f}\right]_{f=0} d z
$$

ここに, $d y$ : 変位, $d_{0}$ : ひび割れがない場合での変位, $E:$ ヤン ク率, $K(z)$ : 作用力による応力拡大係数, $K_{f}(\mathrm{z})$ : 変位を求める部分 の仮想力 $f$ による応力拡大係数である。本式により亀裂を有する 弾性体の任意部変位は応力拡大係数により算出することができる。 求めるべき変位に応じて式(7)に式(5)，(6)の応力拡大係数を代入す ると $\delta_{M}(a, x), \delta_{r}(a, x)$ は以下となる。

$$
\begin{aligned}
\delta_{M}(a, x) & =24 M / d^{2} \int_{x}^{a} \frac{1}{E} F(z, d) \cdot G(z, x, d) d z=M \cdot d_{M}(a, x) \\
\delta_{r}(a, x) & =\int_{0}^{a} \sigma(a, c)\left[\frac{8}{\pi} \int_{x}^{a} \frac{1}{z E} G(z, x, d) \cdot G(z, c, d) d z\right] d c \\
& =\int_{0}^{a} \sigma(a, c) \cdot d_{r}(a, x, c) d c
\end{aligned}
$$


式(8)，(9)を, 式(4)に代入し，Mを消去し整理すると, 結合応 力と開口変位に関する積分方程式，(10)式を得る。本式での $H(a, x$, c) は形状関数であり作用力に依存しない。

$$
\delta(a, x)=\int_{0}^{a} \sigma(a, c) \cdot H(a, x, c) d c
$$$$
; H(a, x, c)=k_{r}(a, c) \cdot d_{p}(a, x) / k_{p}(a)-d_{r}(a, x, c)
$$

材料構成則となる引張軟化曲線は多直線近似式で式(11)で表せ る。 $m(\delta), n(\delta)$ はそれぞれ, 開口変位が $\delta$ での多直線近似式の傾き, Y軸切片である。

$\sigma(a, x)=m(\delta) \cdot \delta+n(\delta) ; \delta=\delta(a, x)$

式(11)に示す引張軟化曲線を式(10)に代入し $\sigma(a, x)$ を消去し離散 化することで, 開口変位 $\delta(a, x)$ に関する非線形連立方程式が得ら れ，それを解くことにより，任意ひび割れ長 $a$ での開口変位の分 布が求められ, さらに式(11)より結合応力の分布が求められる9。 非線形連立方程式の解法では, 各節点の引張軟化曲線の傾き $m$ が一 致するまで連立方程式を繰返し解き最適解を求める(多直線構成関 数一致法 $)^{9)}$ 。結合応力を式(6)に代入し式(3)から $K_{\mathrm{M}}(a)$ を求め, 式 (5)より要素に作用するモーメントMが求められる。

各要素の仮想ひび割れ長さ $a$ での回転角 $\theta(a)$ は, モーメントによ る回転角 $\theta_{M}(a)$ と結合応力による回転角 $\theta_{r}(a)$ の和で下式で表せる。

$$
\theta(a)=\theta_{M}(a)+\theta_{r}(a)
$$

Castiglianoの定理により変形 $\theta$ は弾性変形時, 破壊進展時の工 ネルギーの $M$ による偏微分値の和となる。

$$
\theta=\frac{\partial U_{\text {NoCrack }}}{\partial M}+\frac{2}{E} \int_{0}^{a} K_{\mathrm{I}} \frac{\partial K_{\mathrm{I}_{M}}}{\partial M} d a
$$

式(5)，(6)に示した応力拡大係数を式(13)に代入すると式(14) (15)となり，それらを式(12)に代入しMと $\theta(a)$ との関係が求められ る。 $\theta,(a)$ を求める場合には $M$ を仮想力とし偏微分後 $M=0$ にする。

$$
\begin{aligned}
\theta_{M}(a) & =\theta_{M} \text { Nocract }+\frac{2}{E} \int_{0}^{a} K_{\mathrm{IM}}(z) \frac{\partial K_{\mathrm{IM}}(z)}{\partial M} d z \\
& =\frac{M h}{E I}+\frac{72 \pi M}{E d^{4}} \int_{0}^{a} z \cdot F(z, d)^{2} d z \\
\theta_{r}(a) & =\left(\theta_{M} \text { Nocrack }\right)_{M-0}+\frac{2}{E} \int_{x}^{a} K_{\mathrm{Ir}}(z)\left[\frac{\partial K_{\mathrm{IM}}(z)}{\partial M}\right]_{M=0} d z \\
& =\frac{24}{E d^{2}} \int_{0}^{a} \sigma(a, c)\left[\int_{0}^{a} F(z, d) \cdot G(z, c, d) d z\right] d c
\end{aligned}
$$

求めた回転角から各要素の曲率 $k=\theta / h$ を求め, 平面保持を仮定 し，面積モーメント法により部材全体のたわみの分布を計算する。

\section{3. 実験概要}

\section{1 試験体の概要}

表ー 1 に使用材料を示す。 2 次部材への適用を考慮しセメントに は早強ポルトランドセメントを, 細骨材にはガラス廃材による発泡 人工軽量骨材，混和剤には高性能 $\mathrm{AE}$ 減水剤及びAE郕，短織維には 既報) よりコンクリートの勒性改善効果及び軽量化に有効であると 考察されたビニロン緎維を使用した。水結合材比（W/B）は20\%と した。比較用として普通強度のコンクリートも作製した。表ー 2 に

\begin{tabular}{|c|c|c|}
\hline 記量 & 材 料 & 栍 質 \\
\hline C & セメント & 早強ポルトランドセメント，比重 3.20 \\
\hline SF & シリカフューム & $\mathrm{SiO}_{2} 96.8 \%$ 比董2.20 \\
\hline VF & $\begin{array}{l}\text { ビニロン樴維 } \\
(\mathbf{R F} 4000)\end{array}$ & $\begin{array}{l}\text { 比重 } 1.30 \\
\text { 織維長 } 30 \mathrm{~mm} \text { 、織維径 } 660(\mu \mathrm{m}) \\
\text { 引張強度 } 900(\mathrm{MPa}) 、 \text { ヤンク率 } 30(\mathrm{GPa})\end{array}$ \\
\hline GL & 発泡ガラス情材 & $\begin{array}{l}\text { 号: } 2 \text { 号: } 3 \text { 号 }=8: 1: 1 \text { (重量比) } \\
\text { 最大径 } 5 \mathrm{~mm} \text { ，比重 } 0.70 \text {, 吸水率约 } 7 \%\end{array}$ \\
\hline $\mathrm{SP}$ & 高性能AE淢水剤 & ポリカルボン酸エーテル系 \\
\hline $\mathbf{A E}$ & $\mathrm{AE}$ & アルキルアリルスル尗ン酸化合物系 \\
\hline FA & 起泡剂 & アニオン酸系特殊界面活性㓮 \\
\hline $\mathbf{S}$ & 碀砂 & 八王子市美山産，表軫比重2.62 \\
\hline G & 碎石 & 八王子市美山産，表故比重2.66 \\
\hline
\end{tabular}
試験体の調合条件を示す。混練には容量70リットルのオムニミキ サーを使用した。圧縮強度及びヤング係数測定用に $\phi 100 \times 200 \mathrm{~mm}$ の円柱試験体 3 体, wedge splitting test (以下, くさび割裂試験)用

\begin{tabular}{|c|c|c|c|c|c|c|c|c|c|c|}
\hline \multirow{3}{*}{ 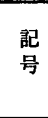 } & \multirow{3}{*}{$\begin{array}{l}\text { 水結 } \\
\text { 合材 } \\
\text { 比 } \\
(\%) \\
\end{array}$} & \multirow{3}{*}{$\begin{array}{l}\text { 添起 } \\
\text { 加萢 } \\
\text { 量 剤 } \\
(\mathrm{B} \times \%)\end{array}$} & \multicolumn{4}{|c|}{ 絶対質量 $\left(\mathrm{kg} / \mathrm{m}^{3}\right)$} & \multicolumn{4}{|c|}{ 気量を $0 \% て ゙$ 計算 } \\
\hline & & & \multirow{2}{*}{$\begin{array}{l}\text { 水 } \\
\mathrm{w}\end{array}$} & \multirow{2}{*}{ 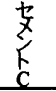 } & \multirow{2}{*}{ 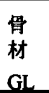 } & \multirow{2}{*}{$\begin{array}{l}\text { 混 } \\
\text { 杨 } \\
\text { SF }\end{array}$} & \multicolumn{3}{|c|}{ 混和剂 } & \multirow{2}{*}{$\begin{array}{l}\text { 峨 } \\
\text { 維 } \\
\text { VF }\end{array}$} \\
\hline & & & & & & & SP & FA & $\mathrm{AE}$ & \\
\hline $\mathbf{L P}$ & \multirow{4}{*}{20} & 0 & 121 & 677 & \multirow{4}{*}{420} & 75 & 30.1 & - & 4.5 & - \\
\hline $\mathbf{L P a}$ & & 1.0 & 113 & 677 & & 75 & 30.1 & 7.5 & 4.5 & - \\
\hline $\mathbf{L F}$ & & 0 & 118 & 660 & & 73 & 29.3 & - & 4.4 & 13.0 \\
\hline LFa & & 1.0 & 110 & 660 & & 73 & 29.3 & 7.5 & 4.4 & 13.0 \\
\hline
\end{tabular}
の試験体 3 体 $(100 \times 100 \times 120 \mathrm{~mm})$ ，パネルの曲げ試験用の試験 体 $(300 \times 100 \times 900 \mathrm{~mm}) 2$ 体を各調合条件毎に作製した。試験体

\begin{tabular}{|c|c|c|c|c|c|}
\hline \multirow[b]{2}{*}{ 記号 } & \multirow[b]{2}{*}{$\begin{array}{l}\text { W/C } \\
(\%)\end{array}$} & \multicolumn{4}{|c|}{ 絶対質量 $\left(\mathrm{kg} / \mathrm{m}^{3}\right)$} \\
\hline & & $\begin{array}{l}\text { 水 } \\
\mathrm{w} \\
\end{array}$ & $\begin{array}{c}\text { セメント } \\
c\end{array}$ & $\begin{array}{c}\text { 細骨材 } \\
\text { S } \\
\end{array}$ & $\begin{array}{c}\text { 粗骨材 } \\
\mathrm{G} \\
\end{array}$ \\
\hline $\mathrm{NC}$ & 65 & 180 & 277 & 756 & 1152 \\
\hline
\end{tabular}

表 -1 使用材料

\begin{tabular}{|c|c|c|c|c|c|c|}
\hline 記 & 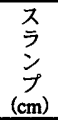 & $\begin{array}{l}7 ス \\
\square ラ \\
1 \text { フ } \\
(\mathrm{cm} \times \mathrm{cm})\end{array}$ & $\begin{array}{l}\text { 比 } \\
\text { 重 }\end{array}$ & $\begin{array}{l}\text { 空 } \\
\text { 気 } \\
\text { 量 } \\
\text { (\%) }\end{array}$ & 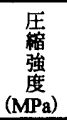 & $\begin{array}{r}ヤ \\
\text { † } \\
\text { 係 } \\
\text { 数 } \\
(\mathrm{GPa}) \\
\end{array}$ \\
\hline$\overline{L P}$ & 25.5 & $50 \times 50$ & 1.29 & 4.73 & 37.4 & 14.7 \\
\hline $\mathbf{L P a}$ & 23.5 & $39 \times 39$ & 1.04 & 23.79 & 17.6 & 8.6 \\
\hline LF & 24.0 & $47 \times 46$ & 1.29 & 4.25 & 41.7 & 13.3 \\
\hline $\mathrm{LFa}$ & 24.5 & $46 \times 46$ & 1.02 & 24.42 & 19.6 & 8.5 \\
\hline $\mathrm{NC}$ & 16.5 & $19 \times 18$ & 2.35 & 0.66 & 27.6 & 29.3 \\
\hline
\end{tabular}

表 -2 試験体の計画調合

a) 樴維補強軽量モルタル

b) 普通コンクリート

表 -3 試験体の性質

*起泡剤添加試料の空気量は打設後の比重と調合から算定

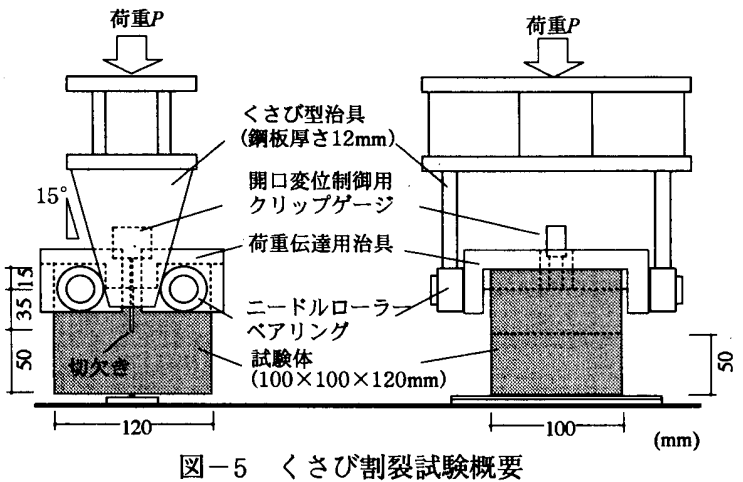

は打設後1日で脱型し, その後 $20^{\circ} \mathrm{C}$ 水中で材路 12 週まで養生し た。表ー 3 に各試験体のフレッシュコンクリートでの性状及び硬化 後の強度性状を示す。

\section{2 くさび割裂試験}

数值解析での材料構成則となる引張軟化曲線は，モード I 型（引 張変形）の破壊が小試験体で得られるくさび割裂試験により評価し

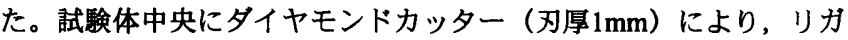
メント高さが50mmとなるように切欠きをいれ，くさびの挿入によ り引張破壊を生じさせる（図-5）。ジグの寸法等はRILEMで提案 している軽量コンクリートのくさび割裂試験方法 ${ }^{10)} に$ 準じた。荷重 変位曲線を精度良く計測するために, クローズドループシステム (閉回路機構) を有するサーボ・コントロール式油圧試験機（MTS 社製）を使用した。本試験機は，クリップゲージによる開口変位計 

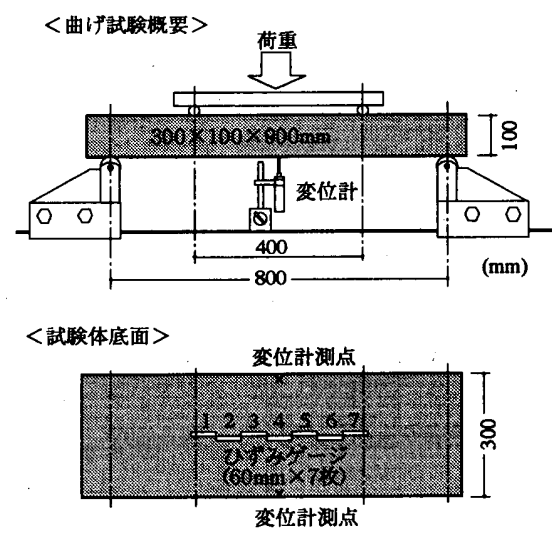

図一－パネル状試験体の曲げ試験概要

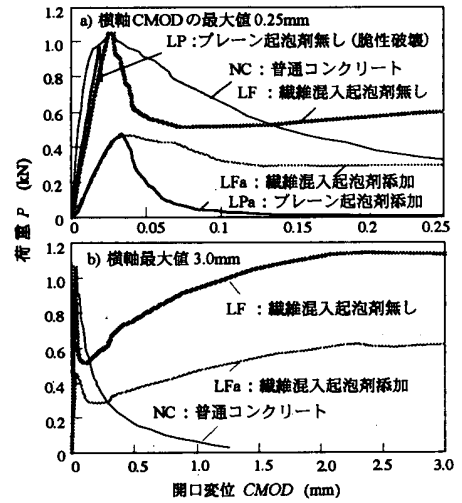

図-7くさび割裂試験での荷重一 開口変位曲線（平均値）

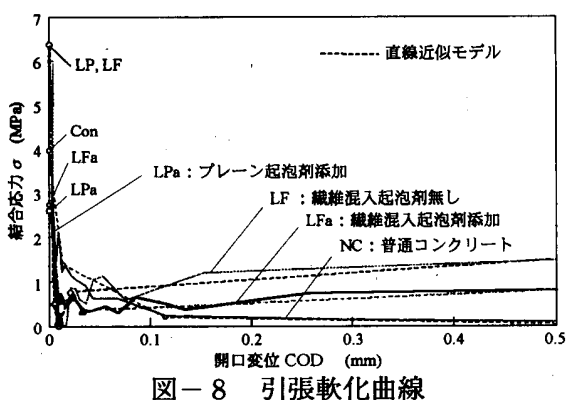

図-8 引張軟化曲線

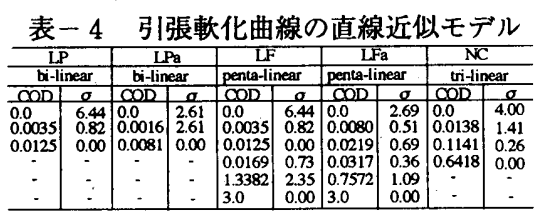

測値をフィードバック信号として，油圧サーボバルブを調節するこ とで変位速度の制御を行うことができる。開口変位 (CMOD) の変 位速度は繊維無混入の軽量コンクリート試験体は脆性的な破壊とな りやすいため $0.0005 \mathrm{~mm} / \mathrm{min}$, 普通コンクリート及び紻維混入試験 体は $0.002 \mathrm{~mm} / \mathrm{min}$ に設定した。CMODの計測には変位制御用の高感 度クリップゲージ（MTS－632.02）を用いた。得られた荷重-CMOD 曲線を基に多直線近似法により引張軟化曲線を求めた。なお,引張 軟化曲線を求める際に必要となるくさび割裂試験での解析諸条件を Appendix IIに示した。

\section{3 パネルの曲げ試験}

図ー6にパネルの曲げ試験の概要を示す。曲げ試験には, 100tonf アムスラー式万能試験機を用い手動載荷とした。支点間のスパン $800 \mathrm{~mm}$, 中央部の載荷スパン $400 \mathrm{~mm}$ の 4 点載荷とし, 試験体のス パン中央両端下部のたわみを計測した。また, 試験体底面には, ひ び割れの発生状況, 分散度等を計測するために, 検長 $60 \mathrm{~mm}$ の歪み ゲージを 7 枚貼り付け計測した。

\section{4. 試験結果及び考察}

4.1 荷重一開口変位曲線

図ー7にくさび割裂試験より得られた荷重一開口変位曲線を示 す。図中には各調合条件ごとの試験体のデータを平均化したものを 示した。緎維無混入の試験体においては, 起泡剤無添加のLPは安 定破壊が得られず脆性的な破壊となった。しかしながら起泡剤を添 加したLPaでは強度はLPよりも低下するが，比較的安定した破壊と

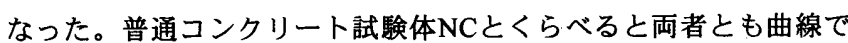
囲まれる面積は小さくエネルギー吸収能は低い。瀻維混入試験体で は, 最大荷重はLF, LFa ともに織維無混入の試験体と同様である が, 最大荷重以降の曲線の伸びが大きくなり勒性が大きく向上して いる。特に最大荷重直後に一旦荷重が低下するが, その後再び荷重 が増加する硬化現象を示している。曲線で囲まれる面積および最大 荷重は; LFに比べ, 気泡混入のLFaの方が小さくなる。これは気泡 の混入によりマトリックス自体の強度低下と伴に織維とペーストと の付着面積が減少し伝達力が隇少するためであると考えられる。

4.2 引張軟化曲線

図一8に多直線近似解析より求めた引張軟化曲線（TSD）を示
す。TSDは荷重一開口変位曲線を反映しており, 荷重一開口変位曲 線で勒性に優れるものはTSDの軟化度が緩やかであり，TSDで囲ま れた面積も大きくなる。䄉維混入試験体においては, 右上がりある いは横這いとなり開口変位が增加しても応力が伝達されている。表 -4 および図 -8 中には, 得られた引張軟化曲線を解析用に直線近 似（2〜5直線）し簡易モデレした結果を示す。なお，LPの引張 軟化曲線はくさび割裂試験で不安定破壊となったため求めることが 出来ず, 同一調合のLFの引張軟化曲線で緎維のブリッジングが生 じる前の初期の直線的な軟化部をLPでの引張軟化曲線とした。

\section{3 パネル試験体の曲げ試験結果}

図ー11にパネルの曲げ試験より得られた荷重一たわみ曲線を示 す。普通コンクリート試験体NCおよび緎維無混入の試験体では最 大荷重以降に一気に脆性的に破壊し安定したデータが得られなかっ た。縬維混入試験体 (LF, LFa) においては, 最大強度は瀻維無混 入試験体とほぼ同様であるが，最大荷重以降すぐには破壊せず延性 的となる。気泡無しのLFは最大荷重以降いったん荷重が低下する が, 徐々に荷重が増加する。気泡混入のLFaは最大荷重以降も荷重 は上昇傾向にあり, いくつかの山がある。

曲け試験終了後のパネルのひび割れ形態を観察した結果， NC， LP，LPaとも大きなひび割れが一本見られた。織維混入試験体に おいては，LFの方は若干のひび割れの細かい分散が見られた。 LFaにおいては，その破壊形態は他の試験体とは大きく異なり，ひ び割れの分散が顕著に現れていた。図ー 9 にひび割れの例を示す。 4.4 パネルの曲げ試験での歪みの変化

図ー10にパネル下面の歪みの計測結果 ( 1 試験体)を示す。普通コ ンクリートNCでは最大荷重以前の $0.4 \mathrm{~mm}$ の変形までは歪みは一様 に分布しているが, 最大荷重付近の $0.5 \mathrm{~mm}$ の変形では一部に大き な歪みが生じており，破壊が局所化している様子が分かる。LP は，最大荷重で一気に破塄したため歪みの局所化は計測できなかう た。気泡を含むLPaでは, NC同様, 最大荷重以前の $0.4 \mathrm{~mm}$ の変形 までは歪みは一様に分布しており, 最大荷重付近の $0.5 \mathrm{~mm}$ の変形 では 2 力所に大きな歪みが生じており破壊が分散している。気泡混 入によりひび割れ分散が生じる理由としては, 空気泡の存在により ひび割れ発生強度が低くなり最大荷重前に表面へのひび割れが多点 に生じること, 空気泡の存在によりひび割れ進展の偏向効果があ り、ひび割れが分散し易いことなどが考えられる。 
織維混入試験体においては, LFでは最大荷重付近の $1.0 \mathrm{~mm}$ の变形 までは歪みが一様に増加していき，最大荷重以降は歪みが集中し破 壊が局所化している。最大荷重前の一様な歪みは, LP等に比較す ると大きく，これは織維のブリッジング作用等により微細なひび割 れが一様に分散発生しているためと考えられる。また特徵的な点と して，最大荷重前の一様な歪みから，歪みが一力所に集中してひび 割れが局所化すると，他の歪みは小さくなり，大きな除荷が生じて いる点である。この場合には，微細ひび割れの閉口（回復）が生じ ているものと考えられる。なお， $5 \mathrm{~mm}$ の変形においても試験体は 破断しなかった。気泡混入によるLFaでは，1 mmの変形ですでに 歪みが数力所に分散しており, 最大荷重以降も歪みは集中すること なく，破境の分散化が顕著であることが分かる。最終的には 5 力所 において大きな歪みを生じており，大きなエネルギーの吸収を生じ ていると推察できる。このようにひび割れ分散が大きくなる理由 は, 䋞維の存在により生じるひずみ硬化過程において，他の要素は マトリックスが気泡を含み低強度であるため, ひび割れが生じやす くなることが考えられる。
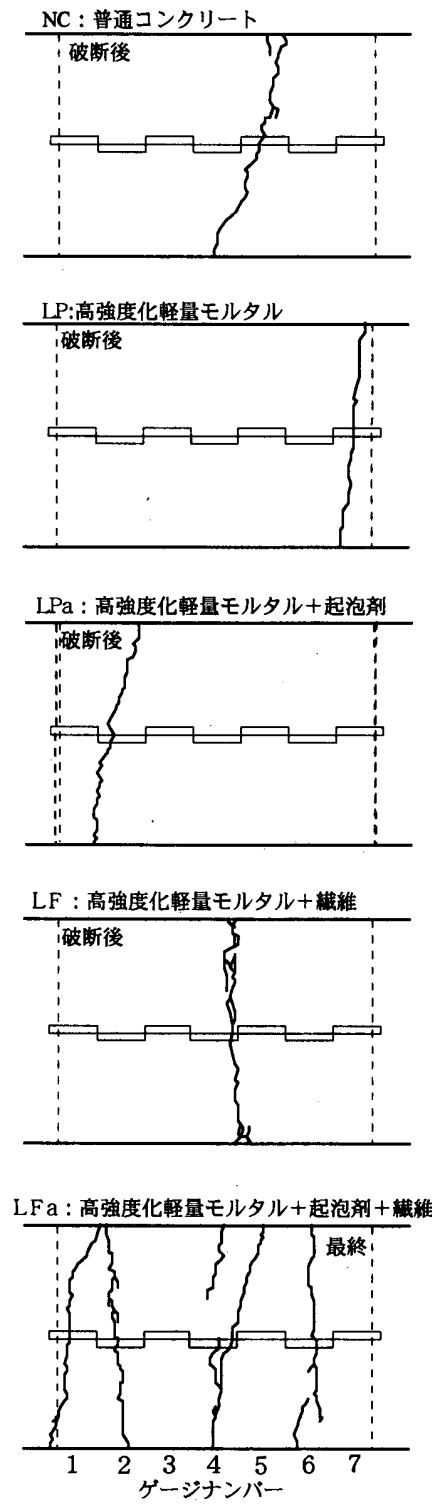

図-9 ひび割れの形態例

\section{5. 解析結果と実䀦結果との目係}

5.1 解析条件

本報で提案した解析方法により曲げ解析を行い，パネル曲げ試験 結果と比較した。試験体の形状・寸法, 加力条件等は実験と同一と した。材料構成則には，引張に関してくさび割裂試験で求め数直線 で近似した引張軟化曲線（表ー4）を用い, 圧縮域は線形弾性とし た。ヤング率は円柱試駧体の圧縮試験結果を用いた。解析要素の幅 $\mathrm{h}$ に関しては，50，100mmに設定して解析した結果，各試験体条 件とも大きな差は認められないこと，実咉結果との対応が最も良い ことなどから今回は $\mathrm{h}=50 \mathrm{~mm}$ 設定し, 純曲げを受けるスパン $400 \mathrm{~mm}$ の部分を 8 要素に分割した。各要素の初期欠宿のモテル化 は, 要素中央に初期切欠きを $1 \mathrm{~mm}$ 刻みで $1 \sim 5 \mathrm{~mm}$ の範囲でラン タムに設定した。図ー3のフローに従って，初期切欠き $5 \mathrm{~mm}$ の最 弱要素のひび割れを進展させ, 最弱要素の軟化及び硬化時のモ一メ ントに応じ各要素の回転角の変化を逐次求めた。さらに回転角から 曲率分布を求めこれを荷重とみなしモーメント図を求めスパン中央 点のたわみを求めた。塑性率 $p は 0,0.5,1.0$ と変化させても解析

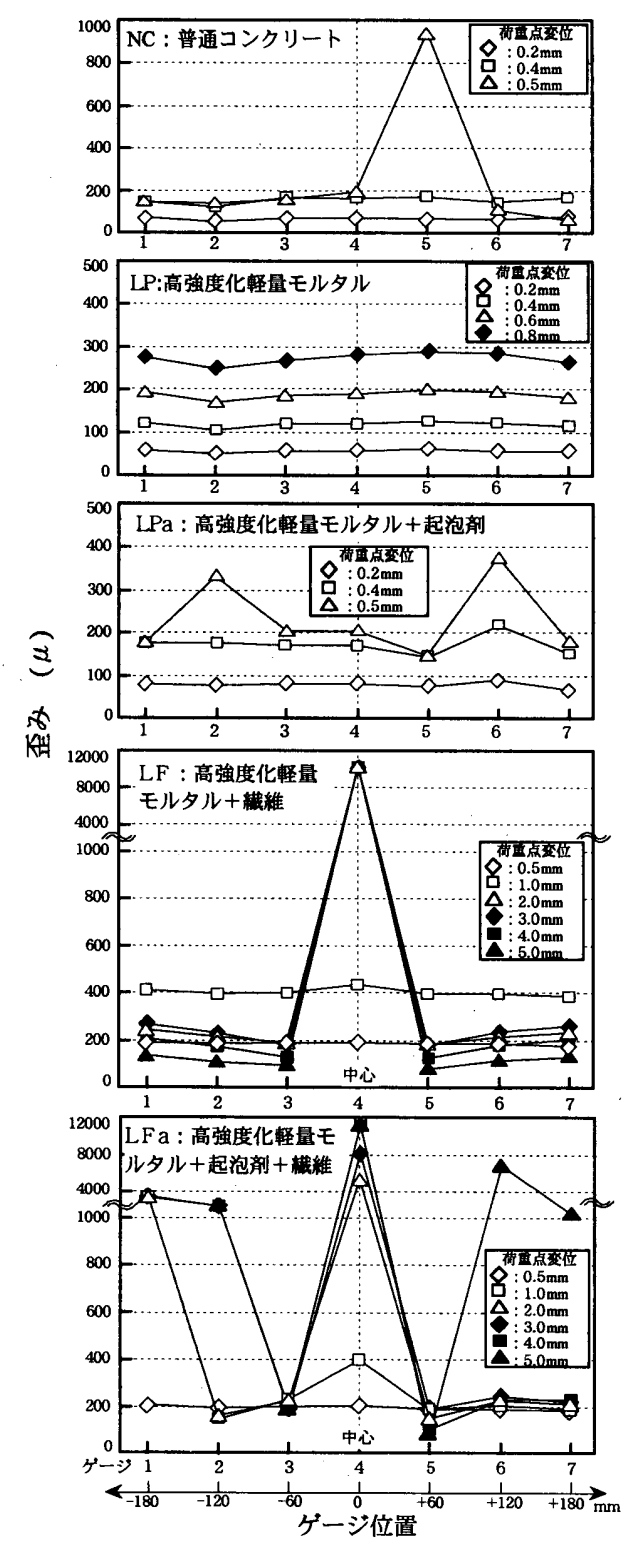

図-10 パネル試験体の歪みの変化

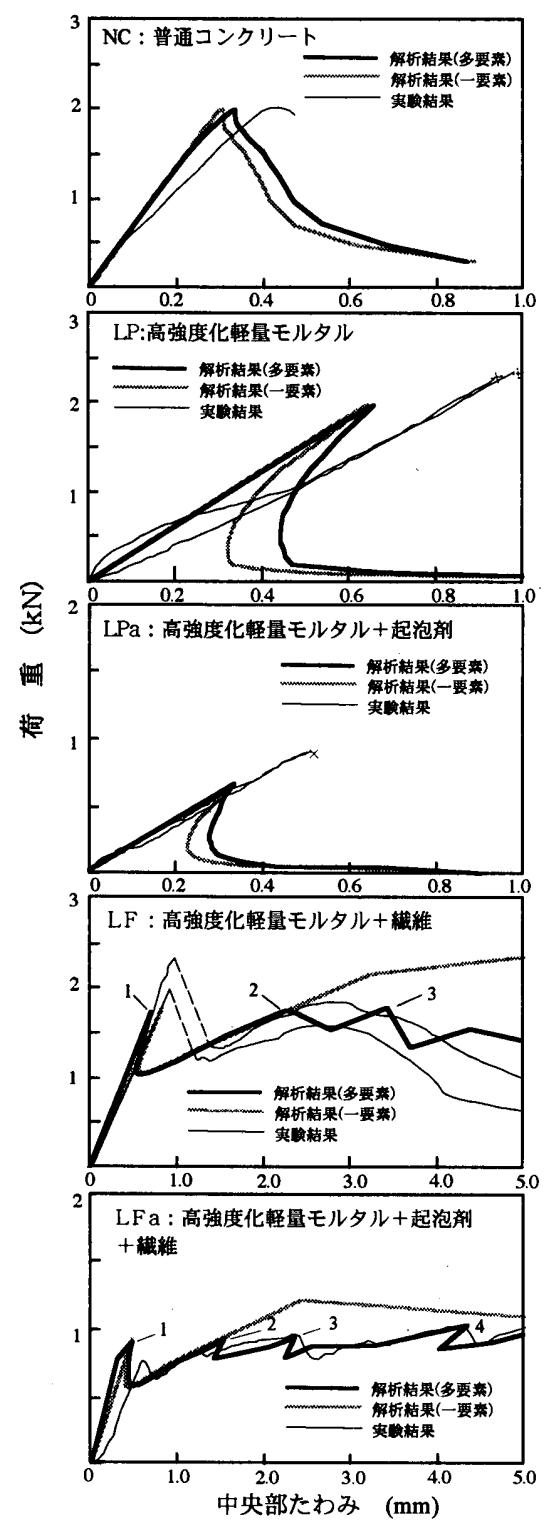

図-11 パネル試験体の荷重一たわみ曲線 


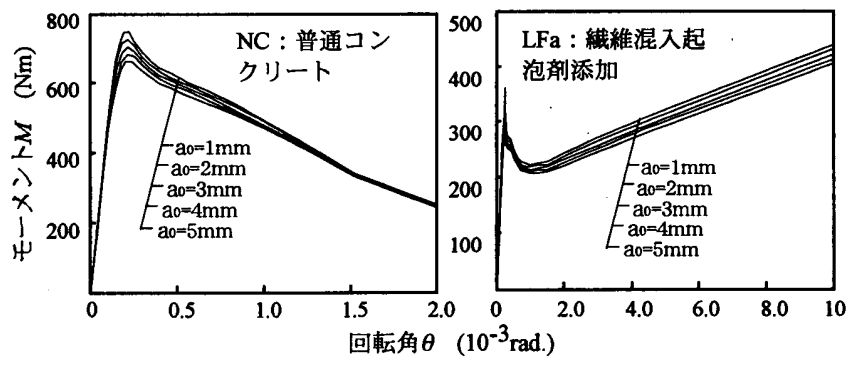

図-12 切欠き長さの異なる要素の回転角モーメント関係例

結果に大きな差は生じなかったため0.5に設定した。

\section{2 解析結果及び考察}

図ー12に解析の過程で計算された各要素のモーメントー回転角 計算例を示す。NCを見ると初期の切欠きが大きい要素ほど最大 モーメントは小さく，他の要素より先にピークとなることが分か る。LFaではピーク荷重後に一端軟化するが途中から硬化し最初の ピーク荷重を超え紻維によるひずみ硬化現象をよく表している。

前出の図-11に, 解析結果と実験結果との関係を合わせて示 す。本解析結果と実験結果とは全体的に良い対応を示している。䄉 維無混入の試験体LP, LPaでは, 最大荷重が実験結果よりもやや 低めとなったが，荷重変位曲線は最大荷重以降変形が戻るスナップ バック現象を示しており，実験結果での不安定破壊をよく表してい るといえる。図中には従来の破壊進展解析で行われている一要素の みに離散ひび割れを生じさせた場合での解析結果を灰色の線で示し た。一要素のみでは最大荷重以降の弾性歪みエネルギーの解放量が 多くなるためLP, LPaではスナップバックの度合いが大きくなっ ている。NCでは, 軟化部分の変形量が少なく評価される。しかし ながら最大荷重までの荷重変形関係はほとんど変わらない。

䋐維混入試験体LF, LFaでは，解析結果と実験結果とは良い对応 を示し, 特に最大荷重以降の変形能を良く表している。解析結果で は最弱要素の硬化に伴う他要素の再載荷および軟化過程が折れ線で 表されており，図中には各要素がピーク荷重となった点を数字で順 番に示した。特にLFaの実験結果に見られる凸凹線之解析結果は良 く一致している。灰色線で示される破壊部を一要素に限定した解析 では他要素の除荷を考慮してないので実験結果との対応は多要素に よる解析よりも良くない。

\section{6. まとめ}

本研究により得られた結論をまとめると以下のとおりである。

1) ひび割れ分散及び局所化を伴う破壊進展を，引張軟化を考慮 した多要素の組合わせによりモデ化し，要素の軟化及び硬化に伴 う除荷及び再載荷を考慮した荷重変位関係の解析方法を提案した。

2) 各種コンクリートパネルの曲げ試験の結果, 短綫維の混入に よりひび割れは分散しエネルギー吸収能は向上する。特に本研究で 使用した空気泡を多量に含ませ軽量化を図った軽量織維補強パネル では大きなひび割れ分散を示した。

3）各種コンクリートパネルの曲げ試験での荷重－変位関係に関 し本解析結果と実験結果とはほぼ対応した。特に䄉維補強材料の最 大荷重以降の軟化及び硬化に伴う変形性能を良く表し得た。

雏辞

本研究を行うにあたり，試料を提供していただいた，山宗化学（株）， （株）サンライト,クラレ（株）に感謝の意を表します。本研究は文部省科 学研究費補助金（基盤 $\mathrm{B}$ ，研究代表者 : 蒸高義典）の助成を受けました。
考文献

1) V. C. Li and E. Liang : Fracture Processes in Concrete and Fiber Reinforced Cementitious Composites, J. of Engrg. Mech., ASCE, 112(6), 566-586. 1986

2）三橋博三，野村希晶，桐越一紀：破壊力学手法に基づく䄉維補強セメン 卜系複合材料の力学特性に関する一考察, 日本建築学会構造系論文報告 集, No.449, pp.1〜7，1993.7.

3）栗原哲彦，安藤貴宏，国枝 稳，内田裕市，六郷恵哲：多直線近似法に よる引張軟化曲線の推定と短䋞維補強コンクリートの曲げ破壊性状, 土 木学会論文集, No.532/V-30, pp.119 129, 1996.2.

4）檑高義典，大岡督尚：高強度モルタルマトリックスの破塤パラメータに 及ほす短織維の影響, 高強度織維補強コンクリート（HFRC）の破壇性 状に関する研究, 日本建築学会構造系論文集, No.497, pp.1-8. 1997.7

5) A. G. Evans : Perspective on the Development of High-toughness Ceramics, J. of Ame. Cer. Soc., Vol. 73, No. 2, pp.187-206, 1990.

6) V. C. Li and C. K. Y. Leung : Steady-State and Multiple Cracking of Short Random Fiber Composites, J. of Engrg. Mech., ASCE, Vol.118, No.11, pp.2246-2264, 1992.

7）橋高義典，高橋仁智，吉岡昌洋：高強度化軽量気泡䄉維補強コンクリー 卜の破壊特性, 日本建築学会構造系論文集, No.528,pp.7-11, 2000.2

8) H. Tada, P. C. Paris and G. R. Irwin: The Stress Analysis of Crack Handbook, Second Edition, Paris Productions Incorporated, 1985.

9）滒高義典，上村克郎，中村成春 : コンクリートの引張軟化曲線の多直線 近似解析, 日本建築学会構造系論文報告集, No.453, pp.15-25, 1993.11

10) RILEM AAC13.1:Determination of the Specific Fracture Energy and Strain Softening of AAC, RILEM Technical Recommendations for the Testing and Use of Construction Materials, pp.156-158,1994

11) G. V. Guinea, M. Elices and J. Planas : Stress Intensity Factors for Wedge-splitting Geometry, Int. J. of Fract. 81, pp.113-124, 1996

Appendix I

本解析で用いた形状関数は以下のとおりである

1) 純曲げ試験体

$F(a, d)=\left(\frac{2}{\pi A} \tan \frac{\pi A}{2}\right)^{0.5} \frac{0.923+0.199(1-\sin (\pi A / 2))^{4}}{\cos (\pi A / 2)},(A=a / d)$

2) ひび割れ面への集中力 $f$ (図A1)

$G(a, c, d)=\frac{G^{\prime}(a, c, d)}{(1-A)^{1.5}\left(1-B^{2}\right)^{0.5}}, \quad(A=a / d, B=c / a)$

$G^{\prime}(a, c, d)=g_{1}(A)+g_{2}(A) \cdot B+g_{3}(A) \cdot B^{2}+g_{4}(A) \cdot B^{3}$

$g_{1}(A)=0.46+3.06 A+0.84(1-A)^{5}+0.66 A^{2}(1-A)^{2}$

$g_{2}(A)=-352 A^{2}$

$g_{3}(A)=6.17-28.22 A+34.54 A^{2}-1439 A^{3}-(1-A)^{1.5}-588(1-A)^{5}-2.64 A^{2}(1-A)^{2}$

$g_{4}(A)=-6.63+25.16 A-31.04 A^{2}+14.41 A^{3}+2(1-A)^{1.5}+5.04(1-A)^{5}+1.98 A^{2}(1-A)^{2}$

Appendix II

くさび割裂試験での荷重変位解析に用いた諸条件は以下のとおりである。 図A2にくさび割裂試験の模式図を示す。試験体寸法は以下である。

$d=85 \mathrm{~mm}, h_{1}=38.5 \mathrm{~mm}, h_{2}=60 \mathrm{~mm}, a_{0}=35 \mathrm{~mm}, t=100 \mathrm{~mm}$

くさび割裂試験での応力払大係数はコンパクトテンションとほぼ同じとみ なせること より, 荷重Pによる応力拡大係数は,

$K_{p}(a)=\sigma_{N}(d-a)^{0.5} \cdot F(a, d)$

ただし

$\sigma_{N}=\sigma_{N \text { ension }}+\sigma_{N \text { bending }}=\frac{P_{H}}{(d-a) t}+\frac{6 P_{H}(a+(d-a) / 2)+6 P_{V} h_{1}}{(d-a)^{2} t}$

$P_{H}=P /(2 \tan \theta), \quad P_{V}=P / 2$

$F(a, d)=(0.05 A+0.95)\left(0.443+2.32 A-6.66 A^{2}+7.36 A^{3}-28 A^{4}\right), \quad(A=a / d)$

ここで，ひび割れ先端の応力計算については，水平力 $P_{\mathrm{H}}$ とともに，鈶直力 Fvにより生じるモーメントも考慮している。

結合力による応力拡大係数, 開口変位及び $\mathrm{CMOD}$ 等の変位計算, ひびわ れ進展解析は本論中の2.2純曲げ破壊解析に示す方法と同様である。
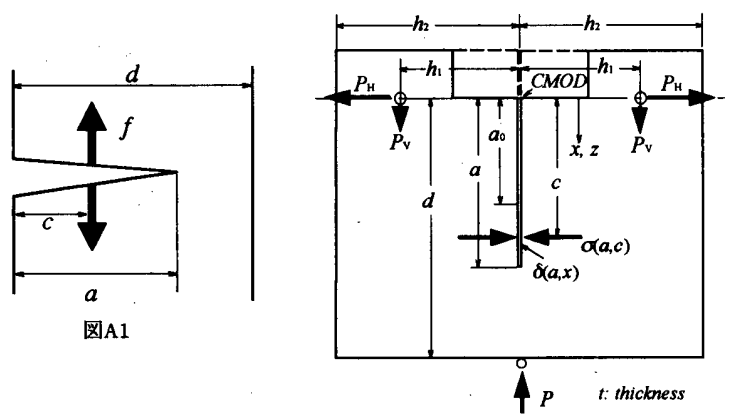

図A2 くさび割裂試倹の試倹体形状

（2000年 5 月 10 日原稿受理，2000年10月 23 日採用決定） 